\title{
PENGARUH GENDER TERHADAP MOTIVASI MEMILIH SEKOLAH DAN PRESTASI BELAJAR
}

\author{
Fatmawati Zahroh \\ Universitas Wisnuwardhana Malang \\ fleurietasmirnov@yahoo.com
}

\begin{abstract}
This research examines the effect between gender on student achievement in SMK PGRI Turen Malang which motivation to choose the school as intervening variabel. Samples of this researh are 100 students consist of 50 female students and 50 male students. Sampling methode was done by purposive sampling. The results showed that: (1) gender have significant direct effect on student achievement; (2) gender have no significant direct effect on motivation to choose the school; (3) motivation to choose the school have no significant effect on student achievement; (5) and there are no significant effect between gender on student achievement which motivation to choose the school as intervening variable.
\end{abstract}

Keywords: Gender, Motivation to choose the school, Student achievement

\begin{abstract}
Abtrak: Penelitian ini menguji pengaruh gender terhadap prestasi belajar siswa di SMK PGRI Turen Malang dimana motivasi memilih sekolah sebagai variabel intervening. Sampel dari penelitian ini sebanyak 100 siswa yang terdiri dari 50 siswa perempuan dan 50 siswa laki-laki. Metode sampling menggunakan purposive sampling. Hasil penelitian menunjukkan bahwa gender berpengaruh langsung terhadap prestasi belajar siswa; (2) gender tidak berpengaruh secara langsung terhadap motivasi memilih sekolah; (3) motivasi memilih sekolah tidak berpengaruh terhadap prestasi belajar siswa; (4) dan gender tidak memiliki pengaruh tidak langsung terhadap prestasi belajar siswa melalui motivasi memilih sekolah.
\end{abstract}

Kata Kunci: Gender, Motivasi memilih sekolah, Prestasi belajar siswa

Pendidikan adalah usaha sadar dan terencana untuk mewujudkan suasana belajar dan proses pembelajaran agar peserta didik aktif mengembangkan potensi dirinya untuk memiliki kekuatan spiritual keagamaan, pengendalian diri, kepribadian, kecerdasan, akhlak mulia, serta keterampilan yang diperlukan dirinya, masyarakat, bangsa, dan negara (Undang-Undang RI Nomor 20, 2003: 5).

Pendidikan merupakan suatu jenjang yang mutlak untuk ditempuh dan sangat bermakna bagi semua kalangan jika ingin maju dan dapat bersaing dengan orang lain untuk menghadapi era globalisasi. Era globalisasi ini menjadikan semua orang bersaing dengan ketat. Orang yang tidak berpendidikan ataupun orang yang berpendidikan 
rendah, akan tersingkir dengan mudahnya dalam persaingan di era ini. Untuk beberapa kalangan terutama kalangan atas, akan sangat mudah untuk memperolah pendidikan setinggi-tingginya dan tentunya akan memberikan peluang yang besar untuk lulus tingkat Sarjana dan dapat berkompetisi di era globalisasi ini.

Berbeda dengan golongan ekonomi lemah, mereka akan mencari alternatif sekolah yang tidak mahal tetapi bisa bersaing dengan lulusan tingkat Sarjana dengan pengalaman praktek kerja di lapangan yang cukup sehingga pendidikan kejuruan menjadi solusi bagi kalangan ini. Pendidikan kejuruan merupakan pendidikan yang mempersiapkan peserta didik untuk dapat bekerja dalam bidang tertentu (UndangUndang RI Pendidikan Nasional No. 20 Tahun 2003: 56).

Sekolah kejuruan menjadi favorit bagi mereka yang ingin mendalami bidangbidang tertentu atau bahkan mereka yang kurang mampu untuk melanjutkan kuliah. Sekolah kejuruan dalam hal ini SMK (SMEA) selalu identik dengan jumlah siswa lakilaki dan perempuan yang tidak seimbang dimana di SMK (SMEA) banyak siswa perempuannya sehingga sudah menjadi label bahwa SMK (SMEA) adalah sekolah untuk perempuan.

Hal inilah yang menjadikan isu gender menarik untuk dikaji lebih lanjut. Gender menurut Handayani dan Sugiarti (2002:6) adalah sifat yang melekat pada kaum laki-laki dan perempuan yang dibentuk oleh faktor-faktor sosial maupun budaya, sehingga lahir beberapa anggapan tentang peran sosial dan budaya laki-laki dan perempuan. Bentukan sosial atas laki-laki dan perempuan itu antara lain: perempuan dikenal sebagai makhluk yang lembut, cantik, emosional, dan keibuan. Sedangkan laki-laki dianggap kuat, rasional, jantan, dan perkasa. Sifat di atas dapat dipertukarkan dan berubah dari waktu ke waktu. Oleh karena itu dapat dikatakan bahwa gender dapat diartikan sebagai konsep sosial yang membedakan (dalam arti: memilih atau memisahkan) peran antara laki-laki dan perempuan. Perbedaan fungsi dan peran antara laki-laki dan perempuan itu tidak ditentukan karena keduanya terdapat perbedaan biologis atau kodrat, tetapi dibedakan atau dipilah-pilah menurut kedudukan, fungsi, dan peranan masing-masing dalam berbagai bidang kehidupan. Perbedaan yang ada pada laki-laki dan perempuan juga terdapat pada otak masing-masing yang menurut Gurian (2005: 43-49) terdiri dari: perbedaan spasial, perbedaan verbal, perbedaan bahan kimia otak, perbedaan cara 
mengikatkan diri, perbedaan tingkat kandungan hormon-hormon, amigdala, hippocampus, ketika otak beristirahat, cingulate gyrus.

Dalam penelitian ini, gender akan dikaitkan dengan motivasi memilih sekolah yang pada akhirnya akan berpengaruh terhadap prestasi belajar siswa. Lebih lanjut, Surya (2003: 106) mengatakan bahwa motivasi berarti suatu dorongan untuk mewujudkan perilaku tertentu yang terarah kepada suatu tujuan tertentu. Motivasi mempunyai karakteristik: (1) sebagai hasil dari kebutuhan, (2) terarah kepada suatu tujuan, (3) menopang perilaku. Motivasi dapat dijadikan sebagai dasar penafsiran, penjelasan, dan penaksiran perilaku. Motif timbul karena adanya kebutuhan yang mendorong individu untuk melakukan tindakan yang terarah kepada pencapaian suatu tujuan. Adapun konsep yang berkaitan dengan motivasi antara siswa laki-laki dan perempuan mungkin akan dibedakan dari sifat yang melekat dari masing-masing individu ini. Berdasarkan perbedaan yang telah dikemukakan Handayani dan Sugiarti (2002:6) serta Gurian (2005) di atas jelaslah bahwa konsep dari sifat masing-masing individu antara perempuan dan laki-laki ini berbeda sehingga akan berdampak pada cara pemikiran yang berbeda pula. Perbedaan pada gender dan motivasi inilah yang diduga menyebabkan perbedaan prestasi belajar siswa di sekolah.

Azwar (1998: 71) mengemukakan bahwa prestasi adalah hasil yang dicapai oleh siswa dalam belajar. Hasil tersebut biasanya harus dilakukan dengan mengadakan penilaian dan pengukuran yang dilaksanakan pada waktu yang telah ditentukan. Jadi dapat disimpulkan bahwa prestasi belajar adalah hasil yang dicapai oleh siswa dalam proses perubahan melalui kegiatannya. Naimah (2007) meneliti pengaruh Nilai Ujian Nasional (NUN) SLTP dan motivasi memilih sekolah terhadap prestasi belajar siswa di SMK Negeri 1 Malang. Hasil penelitian terhadap responden sebanyak 83 siswa kelas I semester I Tahun Pelajaran 2005/2006 menunjukkan bahwa ada pengaruh Nilai Ujian Nasional (NUN) SLTP dan motivasi memilih sekolah terhadap prestasi belajar siswa di SMK Negeri 1 Malang. Lebih lanjut, Praptiningsih ( 2006) menguji hubungan keefektifan guru dalam mengajar dan motivasi berprestasi siswa dengan prestasi belajar siswa pada bidang Akuntansi (Studi pada SMA Ardjuna Malang). Hasil dari penelitian menunjukkan bahwa terdapat hubungan positif antara keefektifan guru dalam mengajar dan motivasi berprestasi siswa dengan prestasi belajar siswa pada bidang Akuntansi (Studi pada SMA Ardjuna Malang). 
Berdasarkan penjelasan tersebut maka dapat dihipotesiskan sebagai berikut:

H1: Terdapat pengaruh langsung antara gender terhadap prestasi belajar siswa

H2: Terdapat pengaruh langsung antara gender terhadap motivasi memilih sekolah

H3: Terdapat pengaruh langsung antara motivasi memilih sekolah terhdap prestasi belajar siswa

H4: Terdapat pengaruh tidak langsung antara gender terhadap prestai belajar siswa melalui motivasi memilih sekolah

\section{METODE}

Penelitian ini termasuk jenis penelitian eksplanasi (explanatory research) yang menguji hubungan antar variabel yang dihipotesiskan (Faisal, 2005: 21). Bentuk hubungan antar variabel dalam penelitian ini adalah hubungan kausal, yaitu hubungan yang bersifat sebab akibat. Penelitian ini berusaha untuk mengetahui pengaruh gender terhadap motivasi memilih sekolah dan prestasi belajar. Model Path Analysis digunakan untuk menganalisis pola hubungan antar variabel dengan tujuan untuk mengetahui pengaruh langsung maupun tidak langsung seperangkat variabel bebas (eksogen) terhadap variabel terikat (endogen) (Riduwan dan Kuncoro, 2007: 2).

Teknik analisis jalur (Path Analysis) akan digunakan dalam menguji besarnya kontribusi yang ditunjukkan oleh koefisien jalur pada setiap diagram jalur dari hubungan kausal antar variabel $\mathrm{D}$ terhadap $\mathrm{X}$ dan $\mathrm{Y}$. Untuk mengetahui derajat hubungan antar variabel gender (D) terhadap motivasi memilih sekolah (X) dengan prestasi belajar (Y) dilakukan penyebaran kuesioner yang bersifat tertutup dan analisis digunakan teknik korelasi yang merupakan dasar dari perhitungan koefisien jalur.

Hubungan antara variabel tersebut dapat digambarkan sebagai berikut:

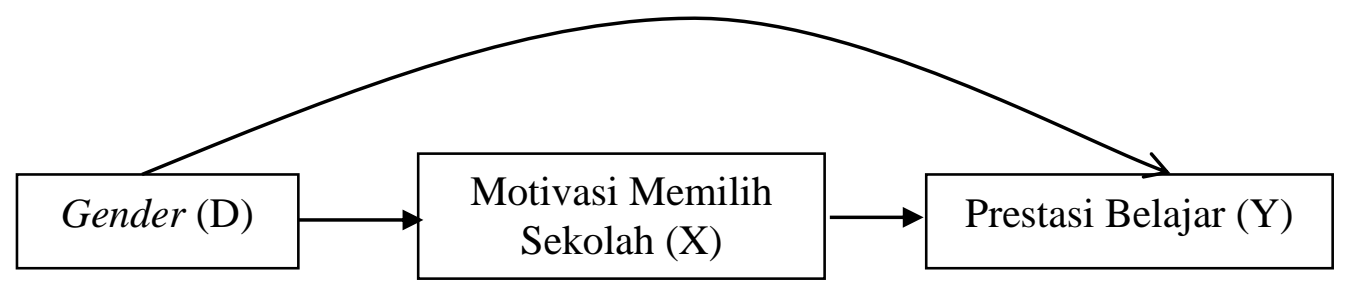

Gambar 1. Hubungan Variabel Bebas dengan Variabel Terikat 
Populasi adalah keseluruhan objek yang ingin diteliti sedangkan sampel adalah sebagian atau wakil dari populasi yang diteliti (Arikunto, 2006: 131). Sampel yang diambil sebanyak 100 siswa yang terdiri dari 50 siswa laki-laki dan 50 siswa perempuan kelas 2 menggunakan purposive sampling. Adapun perincian sampel disajikan dalam tabel berikut:

Tabel 1. Rincian Sampel Penelitian

\begin{tabular}{lccc}
\hline \multicolumn{1}{c}{ Kualifikasi } & Frekuensi & Siswa Laki-Laki & Siswa Perempuan \\
\hline Kelas 2 AK & 38 & 19 & 19 \\
Kelas 2 APK & 22 & 11 & 11 \\
Kelas 2 PJ & 40 & 20 & 20 \\
\hline \multicolumn{2}{c}{ Jumlah } & $\mathbf{5 0}$ & $\mathbf{5 0}$
\end{tabular}

Sumber: (Data diolah)

Pada penelitian ini, pengukuran gender menggunakan variabel dummy yaitu 1 untuk laki-laki dan 0 untuk perempuan. Motivasi memilih sekolah diukur dengan persepsi siswa dengan skala Likert 1-5, mulai sangat setuju, setuju, ragu-ragu, tidak setuju dan sangat tidak setuju. Prestasi belajar dalam penelitian ini diukur dengan menggunakan data nilai terakhir dalam buku rapor siswa yaitu nilai rata-rata dari normatif/adaptif dan rata-rata produktif pada saat kelas 1 semester 2. Adapun pengukuran variabel dijabarkan melalui tabel berikut:

Tabel 2. Jabaran Variabel Penelitian

\begin{tabular}{|c|c|c|c|}
\hline No. & Variabel Penelitian & Sub Variabel & Indikator \\
\hline 1. & Gender & & $\begin{array}{l}\text { - Laki-laki } \\
\text { - Perempuan }\end{array}$ \\
\hline 2. & $\begin{array}{l}\text { Motivasi Memilih } \\
\text { Sekolah }\end{array}$ & $\begin{array}{l}\text { Ketertarikan siswa } \\
\text { kepada sekolah } \\
\text { Pertimbangan yang } \\
\text { menentukan sekolah } \\
\text { mana yang dipilih }\end{array}$ & $\begin{array}{l}\text { - Biaya selama sekolah } \\
\text { - Rasa bangga kepada } \\
\text { sekolah } \\
\text { - Tujuan memilih sekolah } \\
\text { - Kecerdasan } \\
\text { - Prestasi di SLTP } \\
\text { - Keadaan sarana dan } \\
\text { prasarana sekolah }\end{array}$ \\
\hline & & $\begin{array}{l}\text { Pihak-pihak yang } \\
\text { kuat dalam }\end{array}$ & - Orang tua \\
\hline
\end{tabular}




\begin{tabular}{|c|c|c|}
\hline & $\begin{array}{l}\text { menentukan pilihan } \\
\text { - Program yang } \\
\text { diaplikasikan SMK } \\
\text { (SMEA) }\end{array}$ & 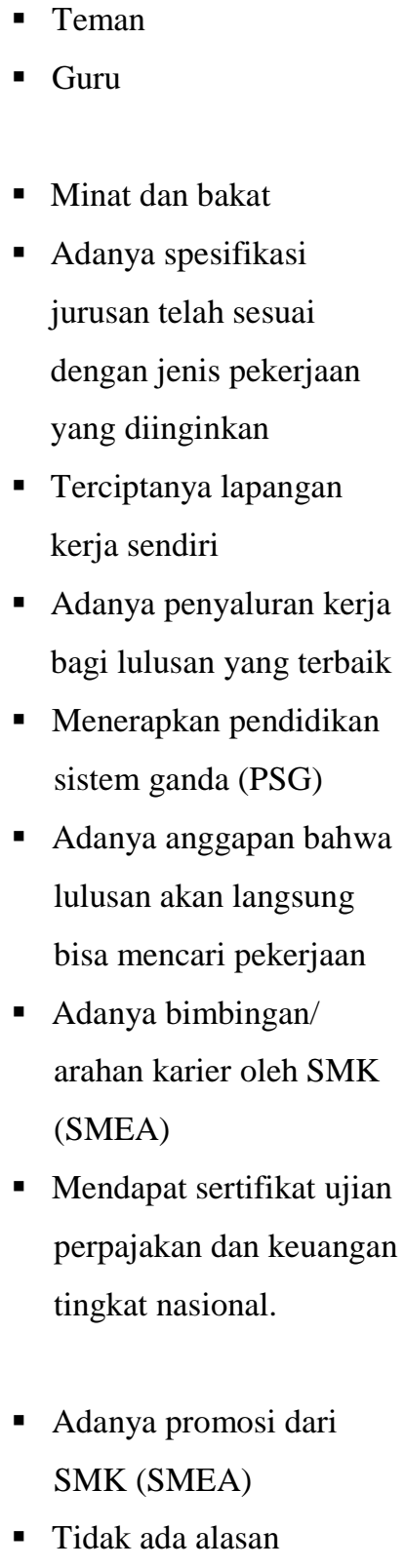 \\
\hline 3. $\quad$ Prestasi belajar siswa & Hasil raport terakhir & $\begin{array}{l}\text { Nilai terakhir yang di rata- } \\
\text { rata yang diperoleh dalam } \\
\text { raport }\end{array}$ \\
\hline
\end{tabular}

Uji validitas dilakukan untuk mengukur dan menunjukkan tingkat kevalidan atau kesahihan suatu data yang dihasilkan dari suatu instrumen. Pengujian validitas tiap butir item ini dilakukan dengan mengkorelasikan skor tiap butir soal dengan skor total. Syarat minimum suatu instrumen dianggap memenuhi syarat validitas adalah apabila nila $\mathbf{r}_{\text {hitung }}$ $>\mathrm{r}_{\text {tabel. }}$. Berdasarkan hasil analisis data menggunakan Pearson Correlation dengan $\mathrm{N}$ of item 20 pada taraf signifikansi 0,05 dan $r_{\text {tabel }}$ 0,361 memperoleh hasil bahwa 20 butir 
soal mempunyai $\mathrm{r}_{\text {hitung }}>\mathrm{r}_{\text {tabel. }}$. Dengan demikian butir soal dikatakan mempunyai tingkat validitas tinggi.

Pengujian reliabilitas dilakukan dengan melihat angka alpha, apabila nilai koefisien alpha semakin mendekati angka 1, maka instrumen dikatakan mempunyai tingkat reliabilitas yang tinggi dan apabila sebaliknya maka instrumen dikatakan tidak reliabel. Hasil analisis yang dilakukan dengan menggunakan program SPSS for Windows 11.0 menunjukkan bahwa 20 item butir soal mempunyai tingkat koefisien alpha 0,8863 yang mendekati angka 1 sehingga dapat disimpulkan bahwa instrument ini mempunyai tingkat reliabilitas tinggi.

\section{HASIL DAN PEMBAHASAN}

\section{Hasil}

Berikut adalah data nilai rata-rata rapor siswa laki-laki kelas 2 SMK PGRI Turen Malang.

Tabel 3. Nilai Rata-Rata Rapor Siswa Laki-Laki Kelas 2

\begin{tabular}{cllcc}
\hline No. & \multicolumn{1}{c}{ Nilai Rata-Rata Rapor } & \multicolumn{1}{c}{ Kategori } & Frekuensi & Persentase \\
\hline 1. & $9,00-10,00$ & Sangat Tinggi & 0 & $0 \%$ \\
2. & $8,00-8,99$ & Tinggi & 0 & $0 \%$ \\
3. & $7,00-7,99$ & Sedang & 29 & $58 \%$ \\
4. & $6,00-6,99$ & Rendah & 21 & $42 \%$ \\
5. & $0,00-5,99$ & Sangat Rendah & 0 & $0 \%$ \\
\hline & & & 50 & $100 \%$
\end{tabular}

Sumber: (data diolah)

Berdasarkan tabel 3 diatas dapat diketahui bahwa prestasi belajar siswa laki-laki kelas 2 di SMK PGRI Turen Malang tergolong sedang, hal ini ditunjukkan oleh tidak adanya pencapaian prestasi pada kategori sangat tinggi dan tinggi, 58\% siswa laki-laki tergolong pada kategori prestasi sedang, 42\% pada kategori prestasi rendah, dan tidak ada siswa laki-laki pada kategori prestasi sangat rendah. Berikut disajikan nilai rata-rata rapor siswa perempuan kelas 2 . 
Tabel 4. Nilai Rata-Rata Rapor Siswa Perempuan Kelas 2

\begin{tabular}{cllcc}
\hline No. & Nilai Rata-Rata Rapor & \multicolumn{1}{c}{ Kategori } & Frekuensi & Persentase \\
\hline 1. & $9,00-10,00$ & Sangat Tinggi & 0 & $0 \%$ \\
2. & $8,00-8,99$ & Tinggi & 1 & $2 \%$ \\
3. & $7,00-7,99$ & Sedang & 43 & $86 \%$ \\
4. & $6,00-6,99$ & Rendah & 6 & $12 \%$ \\
5. & $0,00-5,99$ & Sangat Rendah & 0 & $0 \%$ \\
\hline & & & 50 & $100 \%$
\end{tabular}

Sumber: (Data diolah)

Berdasarkan tabel 4 diatas diketahui bahwa prestasi belajar siswa perempuan kelas 2 di SMK PGRI Turen Malang tergolong sedang, hal ini ditunjukkan oleh tidak ada pencapaian prestasi pada kategori sangat tinggi, $2 \%$ siswa perempuan tergolong pada prestasi tinggi, $86 \%$ pada kategori prestasi sedang, $12 \%$ pada kategori prestasi rendah, dan tidak ada siswa perempuan pada kategori prestasi sangat rendah.

Hipotesis 1 yang diajukan dalam penelitian ini adalah terdapat pengaruh langsung antara gender dengan prestasi belajar siswa. Hasil analisis disajikan pada tabel dibawah ini.

Tabel 5. Pengujian Hipotesis 1

\begin{tabular}{llcc}
\hline Variabel Dummy & Standardized Coefficient Beta & T & Sig \\
\hline Gender & 0.340 & 3.583 & 0.001 \\
\hline Variabel Terikat & $:$ Prestasi Belajar Siswa & & \\
Konstanta & $: 72.377$ & & \\
R Square & $: 0.116$ & & \\
\hline
\end{tabular}

Sumber: (Data diolah)

Berdasarkan hasil pengujian pada tabel 5 diatas terlihat nilai t sebesar 3,583 dengan signifikansi 0,001 , kemudian nilai signifikansi 0,001 lebih besar daripada nilai probabilitas 0,05 atau 0,05>0,001; maka Ho ditolak dan Ha diterima artinya analisis jalur adalah signifikan. Jadi dapat disimpulkan bahwa gender berpengaruh langsung terhadap prestasi belajar siswa di SMK PGRI Turen Malang. Besarnya koefisien determinasi ( $R$ Square) sebesar 0,116. Koefisien determinasi sebesar 0,116 menunjukkan besarnya kontribusi variabel gender terhadap prestasi belajar siswa sebesar $11,6 \%$ sedangkan sisanya merupakan kontribusi dari variabel lain diluar model regresi ini. 
Hipotesis 2 yang diajukan dalam penelitian ini adalah terdapat pengaruh langsung gender terhadap motivasi memilih sekolah. Hasil analisis disajikan pada tabel dibawah ini.

Tabel 6. Pengujian hipotesis 2

\begin{tabular}{|c|c|c|c|}
\hline Variabel Dummy & $\begin{array}{c}\text { Standardized } \\
\text { Coefficient Beta }\end{array}$ & $\mathbf{T}$ & Sig \\
\hline Gender & -0.053 & -0.530 & 0.597 \\
\hline $\begin{array}{ll}\text { Variabel Bebas } & : \\
\text { Konstanta } & : \\
\text { R Square } & :\end{array}$ & $\begin{array}{l}\text { : Motivasi Memilih Sekolah } \\
: 26.012 \\
: 0.003\end{array}$ & & \\
\hline
\end{tabular}

Sumber: (Data diolah)

Berdasarkan pada tabel 6 diatas terlihat nilai t sebesar 0,053 dengan signifikansi 0,597, kemudian nilai signifikansi 0,597 lebih besar daripada nilai probabilitas 0,05 atau 0,05<0,597; maka Ho diterima dan Ha ditolak artinya analisis jalur adalah tidak signifikan. Jadi dapat disimpulkan bahwa gender tidak berpengaruh langsung terhadap motivasi memilih sekolah di SMK PGRI Turen Malang. Besarnya koefisien determinasi ( $R$ Square) sebesar 0,003. Koefisien determinasi sebesar 0,003 menunjukkan besarnya kontribusi variabel gender terhadap motivasi memilih sekolah sebesar 3\% sedangkan sisanya merupakan kontribusi dari variabel lain diluar model regresi ini.

Hipotesis 3 yang diajukan dalam penelitain ini adalah terdapat pengaruh langsung antara motivasi memilih sekolah dengan prestasi belajar siswa. Hasil analisis disajikan pada tabel berikut.

Tabel 7. Pengujian hipotesis 3

\begin{tabular}{llcc}
\hline \multicolumn{1}{c}{ Variabel Bebas } & \multicolumn{1}{c}{$\begin{array}{c}\text { Standardized } \\
\text { Coefficient Beta }\end{array}$} & T & Sig \\
\hline $\begin{array}{l}\text { Motivasi Memilih } \\
\text { Sekolah }\end{array}$ & \multicolumn{1}{c}{-0.089} & -0.889 & 0.379 \\
\hline Variabel Terikat & $:$ Prestasi Belajar Siswa & & \\
Konstanta & $: 28.471$ & & \\
R Square & $: 0.008$ & & \\
\hline
\end{tabular}

Sumber: (Data diolah)

Berdasarkan pada tabel 7 diatas terlihat nilai t sebesar -0,889 dengan signifikansi 0,379, kemudian nilai signifikansi 0,379 lebih besar daripada nilai probabilitas 0,05 atau 0,05<0,379; maka Ho diterima dan Ha ditolak artinya analisis jalur adalah tidak signifikan. Jadi dapat disimpulkan bahwa motivasi memilih sekolah tidak berpengaruh langsung terhadap prestasi belajar siswa di SMK PGRI Turen Malang. Besarnya 
koefisien determinasi ( $R$ Square) sebesar 0,008. Koefisien determinasi sebesar 0,008 menunjukkan besarnya kontribusi variabel motivasi memilih sekolah terhadap prestasi belajar siswa sebesar $8 \%$ sedangkan sisanya merupakan kontribusi dari variabel lain diluar model regresi ini.

Hipotesis 4 yang diajukan dalam penelitian ini adalah terdapat pengaruh tidak langsung antara gender terhadap prestasi belajar melalui motivasi memilih sekolah. Setelah mengetahui pengaruh secara langsung dari masing-masing variabel dummy terhadap variabel bebas terhadap variabel terikat baik pada persamaan regresi pertama, kedua, ketiga dan keempat. Maka selanjutnya dihitung pengaruh tidak langsung gender (D) terhadap prestasi belajar siswa (Y) melalui motivasi memilih Sekolah. Untuk memudahkannya terlebih dahulu disusun model lintasan dalam analisis jalur sebagai berikut:

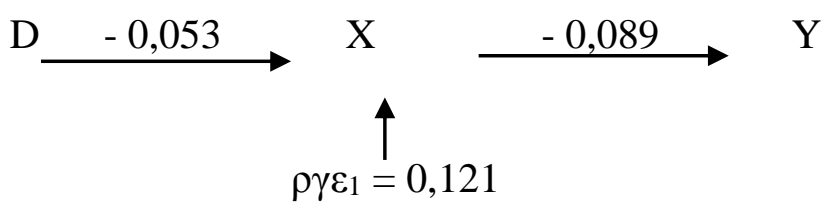

Pengaruh tidak langsung variabel bebas terhadap variabel terikat tampak pada model lintasan di atas maka diperoleh rumus:

PTL $\left(\right.$ D-Y) $=$ P1 $_{1} \times$ P2 $_{2}$

Keterangan:

PTL $(\mathrm{D}-\mathrm{Y})=$ Pengaruh tidak langsung variabel D terhadap variabel terikat

$\mathrm{P}_{1} \quad=$ Pengaruh langsung variabel $\mathrm{D}$ terhadap $\mathrm{X}$

$\mathrm{P}_{2} \quad=$ Pengaruh langsung variabel $\mathrm{X}$ terhadap $\mathrm{Y}$

Dengan demikian dapat dihitung pengaruh tidak langsung variabel dummy (D) terhadap variabel terikat $(\mathrm{Y})$ melalui variabel bebas $(\mathrm{X})$ seperti yang dijelaskan sebagai berikut:

PTL $(D-Y)=(-0,053) \times(-0,089)=0,0047$

Total pengaruh langsung dan total pengaruh tidak langsung yang didapat dari model lintasan jalur:

Total pengaruh D-Y $=(-\mathbf{0 , 0 5 3})+\mathbf{0 , 0 0 4 7}=\mathbf{- 0 , 0 4 8 3}$

Kemudian dari beberapa hasil perhitungan di atas ini dapat ditarik kesimpulan bahwa tidak ada pengaruh tidak langsung gender terhadap prestasi belajar melalui motivasi memilih sekolah. 


\section{Pembahasan}

Penelitian ini telah menghasilkan bukti bahwa ada pengaruh langsung gender terhadap prestasi belajar siswa (hipotesis 1) dengan taraf signifikansi 0,001. Hal ini sejalan dengan yang dikemukakan oleh Gulian (2005) bahwa senyatanya, aliran darah dalam otak perempuan lebih banyak 15\% daripada dalam otak lelaki, dan ada lebih banyak pusat otak perempuan yang bercahaya dibandingkan dengan pusat otak lelaki. Berpijak dari teori itulah kemungkinan yang sangat mendukung bahwa perempuan akan lebih berprestasi daripada laki-laki karena dipandang dari segi otaknya. Lebih lanjut, penelitian ini dilakukan di SMK (SMEA) yang mempunyai image bahwa SMK (SMEA) adalah sekolah perempuan, dan yang terpenting adalah jurusan yang ada pada SMK (SMEA) yaitu jurusan yang membutuhkan tingkat ketelitian tinggi misalkan jurusan akuntansi, dibuktikan bahwa siswa laki-laki biasanya tidak teliti dalam mengerjakan soal akuntansi, maka pencapaian tingkat prestasi antara siswa laki-laki dan perempuan berbeda, dan terbukti dalam penelitian ini, siswa perempuan prestasinya lebih tinggi daripada siswa laki-laki .

Hipotesis kedua yang menyatakan terdapat pengaruh gender terhadap motivasi memilih sekolah tidak didukung. Dalam penelitian ini penulis menyimpulkan bahwa motivasi memilih sekolah antara siswa laki-laki dan siswa perempuan sama. Seperti yang dikemukakan Dimyati (2002: 80) bahwa ada tiga komponen utama dalam motivasi, yaitu (i) kebutuhan, (ii) dorongan, dan (iii) tujuan. Kebutuhan terjadi bila individu merasa ada ketidakseimbangan antara apa yang ia miliki dan yang ia harapkan. Dorongan merupakan kekuatan mental untuk melakukan kegiatan dalam rangka memenuhi harapan atau mencapai tujuan. Dorongan yang berorientasi pada tujuan tersebut merupakan inti motivasi. Sedangkan tujuan adalah hal yang ingin dicapai oleh seorang individu. Oleh karena itu, jelaslah bahwa motivasi itu timbul karena kebutuhan, dorongan, dan tujuan. Hal ini berarti bahwa seseorang akan mempunyai motivasi yang sama jika mempunyai kebutuhan, dorongan, dan tujuan yang sama. Mungkin tidak semua orang mempunyai dorongan yang sama, akan tetapi memungkinkan mempunyai kebutuhan dan tujuan yang sama antara siswa laki-laki dan siswa perempuan dikarenakan masuk sekolah yang sama dan sama-sama ingin lulus dengan predikat baik. 
Maka akan menghasilkan motivasi yang sama walaupun tidak sama persis antara siswa laki-laki dan siswa perempuan.

Hipotesis ketiga yang menyatakan bahwa terdapat pengaruh langsung antara motivasi memilih sekolah terhadap prestasi belajar siswa tidak terbukti.. Hasil dalam penelitian ini tidak sejalan dengan penelitian terdahulu yang dilakukan oleh Naimah (2007) yang menunjukkan bahwa ada pengaruh yang signifikan motivasi terhadap prestasi belajar, karena dalam penelitian Naimah (2007) menunjukkn data bahwa tingkat motivasi yang tinggi menimbulkan pencapaian prestasi yang tinggi pula sehingga terdapat pengaruh yang signifikan antara kedua variabel tersebut. Lebih lanjut, Slameto (2003: 54-72) menyebutkan bahwa hasil belajar atau prestasi belajar siswa dapat diketahui melalui penilaian prestasi belajar atau rapor. Hasil belajar yang dicapai tiap-tiap anak tidaklah sama, hal ini disebabkan adanya beberapa faktor baik dari dalam diri anak (internal) maupun dari luar diri anak tersebut. Faktor internal meliputi: faktor jasmani, psikologi, dan faktor kelelahan. Sedangkan faktor eksternal dari luar diri siswa meliputi: faktor keluarga, sekolah, dan masyarakat.

Dari faktor-faktor intern dan ekstern yang dikemukakan oleh Slameto (2003), jelaslah bahwa prestasi belajar tidak hanya dipengaruhi oleh motivasi siswa, akan tetapi banyak hal yang dapat mempengaruhi. Sedangkan dalam penelitian ini hanya mencari pengaruh motivasi terhadap prestasi siswa. Jadi dapat disimpulkan bahwa prestasi belajar siswa di SMK PGRI Turen ini juga tidak mutlak dipengaruhi oleh tingkat motivasi siswa, akan tetapi banyak faktor yang mempengaruhi, dan memungkinkan pengaruh yang besar, tidak pada faktor motivasi, akan tetapi faktor lain, sehingga dalam penelitian ini motivasi tidak berpengaruh langsung terhadap prestasi belajar siswa SMK PGRI Turen Malang.

Hipotesis keempat yang menyatakan bahwa terdapat pengaruh tidak langsung gender terhadap prestasi belajar melalui motivasi memilih sekolah tidak terbukti. Variabel motivasi memilih sekolah tidak memediasi hubungan gender dan prestasi belajar siswa. Menurut Azwar (1998: 71) prestasi adalah hasil yang dicapai oleh siswa dalam belajar. Hasil tersebut biasanya harus dilakukan dengan mengadakan penilaian dan pengukuran yang dilaksanakan pada waktu yang telah ditentukan. Dari teori tersebut dan penelitian ini dipadukan, maka dapat disimpulkan bahwa walaupun motivasi terbukti sama, akan tetapi tidak menjadi jaminan bahwa motivasi mutlak 
menjadi ukuran pencapaian tingkat prestasi yang sama, akan tetapi pencapaian prestasi akan berbeda juga dikarenakan proses belajar tiap individu yang berbeda pula.

\section{SIMPULAN}

Berdasarkan penelitian ini dapat disimpulkan bahwa: (1) gender memiliki pengaruh langsung terhadap prestasi belajar siswa; (2) gender tidak berpengaruh terhadap motivasi siswa dalam memilih sekolah; (3) motivasi memilih sekolah tidak berpengaruh terhadap prestasi belajar siswa; (4) dan tidak terdapat pengaruh tidak langsung antara gender terhadap prestasi belajar siswa yang dimediasi oleh motivasi siswa dalam memilih sekolah. Penelitian ini memiliki keterbatasan dimana penelitian hanya dilakukan pada siswa kelas 2 di SMK PGRI Turen Malang, sehingga hasil penelitian tidak dapat digeneralisasi. Variabel yang dianggap mempengaruhi tingkat prestasi belajar siswa di dalam penelitian ini hanya gender dan motivasi memilih sekolah, padahal masih banyak variabel lain yang dapat mempengaruhi tingkat prestasi belajar siswa. Variabel lain itu misalnya faktor intern ataupun faktor ekstern dari siswa tersebut, kondisi fasilitas mengajar, cara mengajar guru, dan lain-lain.

Dengan memperhatikan hasil temuan dalam penelitian ini, maka dalam kesempatan ini Penulis bermaksud menyampaikan saran-saran dengan harapan agar memiliki kemanfaatan yang berarti bagi banyak pihak. Saran dari penelitian ini sebaiknya menggunakan sampel yang lebih luas dengan wilayah populasi yang besar sehingga diharapkan akan mengungkap lebih banyak permasalahan dan memberikan hasil temuan penelitian yang lebih berarti bagi banyak pihak sekaligus menggunakan random dalam metode penyampelannya.

\section{DAFTAR RUJUKAN}

Arikunto, Suharsimi. 2006. Prosedur Penelitian: Suatu Pendekatan Praktik. Jakarta: PT Rineka Cipta

Azwar, Saifudin. 1998. Fungsi dan Pembangunan Prestasi Belajar. Yogyakarta: Pustaka Pelajar. 
Dimyati dan Mudjiono. 2002. Belajar dan Pembelajaran. Jakarta: Pusat Pembukuan Departemen Pendidikan dan Kebudayaan dan PT Rineka Cipta.

Faisal, Sanafiah. 2005. Format-Format Penelitian: Dasar-Dasar dan Aplikasinya. Jakarta: Rajawali Press.

Gurian, Michael. 2003. Apa Sih yang Si Abang Pikirkan: Membedah Cara Kerja Otak Laki-Laki. Terj. Agung Prihantoro. 2005. Jakarta: PT Serambi Ilmu Semesta.

Handayani, Trisakti dan Sugiarti. 2002. Konsep dan Teknik Penelitian Gender. Malang: UMM Press.

Naimah, Jannatun. 2007. Pengaruh Nilai Ujian Nasional (NUN) SLTP dan Motivasi Memilih Jurusan terhadap Prestasi Belajar Siswa di SMK Negeri 1 Malang. Skripsi tidak diterbitkan. Universitas Negeri Malang.

Praptiningsih, Arie. 2007. Hubungan Keefektifan Guru dalam Mengajar dan Memotivasi Berprestasi Siswa dengan Prestasi Belajar Siswa pada Bidang Akuntansi (Studi pada SMA Ardjuna Malang). Skripsi tidak diterbitkan. Universitas Negeri Malang

Riduwan dan Engkos Achmad Kuncoro. 2007. Cara Menggunakan dan Memakai Analisis Jalur (Path Analysis). Bandung: Alfabeta.

Slameto. 2003. Belajar dan Faktor-Faktor yang Mempengaruhinya. Jakarta: Rineka Cipta.

Undang-Undang Republik Indonesia No. 2 Tahun 1989 Tentang Sistem Pendidikan Nasional. Jakarta: Kloang Klede Jaya.

Undang-Undang Republik Indonesia No. 20 Tahun 2003 Tentang Sistem Pendidikan Nasional. Bandung: Citra Umbara. 